See discussions, stats, and author profiles for this publication at: https://www.researchgate.net/publication/342458325

\title{
Communicating religious extremism in West Africa
}

Chapter · June 2020

DOI: 10.4324/9781003017080-12

CITATIONS

3 authors:

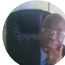

Innocent Chiluwa

Covenant University Ota Ogun State, Nigeria

75 PUBLICATIONS 636 CITATIONS

SEE PROFILE

A. Esther Ajiboye

IU: Covenant University Ota Ogun State, Nigeria

26 PUBLICATIONS 76 CITATIONS

SEE PROFILE

Some of the authors of this publication are also working on these related projects:
READS

252

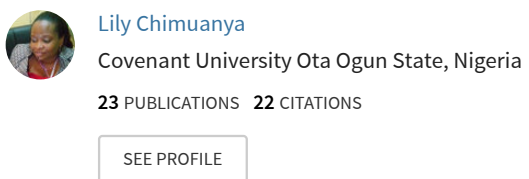

Project $\quad$ Stance View project

Investigation of the Compressive, Split Tensile and Flexural Characteristics of Steel Scrap Composite Concrete View project 
Accepted version

\title{
Communicating Religious Extremism in West Africa
}

\author{
In: Themes in Religion and Human Security in Africa edited by Joram Tarusarira and Ezra \\ Chitando London: Routledge, 2021.
}

\author{
Innocent Chiluwa, Lily Chimuanya \& Esther Ajiboye \\ Department of Languages \& General Studies \\ Covenant University, OTA, Nigeria
}

\begin{abstract}
Whereas modern communication strategies have been celebrated for promoting ease of interaction, this chapter highlights that they have been deployed by some terrorist groups in Africa to threaten human security. It defines religious extremism in terms of the expression of extreme or violent actions or jihad on the basis of particular interpretations or understanding of religious teaching or scripture, especially the Quran. The chapter examines the (online) communication behaviours of extremists/terrorist groups in West Africa and Somalia that are often associated with Islam. It also examines religious extremism and its relation to violent conflict and describes the extremist violent activities of some identified African terrorist groups, and how contemporary media and the Internet have provided dynamic platforms for disseminating their message and ideology. Liebman views religious extremism as the desire to expand the scope, details and strictness of religious law, social isolation and the rejection of the surrounding culture.
\end{abstract}

\section{Introduction}

Extremism is often associated with religion and has in recent years been used exclusively in the context of religion due to the activities of religious extremists and terrorists who explain their actions as an expression of religious obligation. Some scholars have argued that certain unique features of religion make it susceptible to violent conflicts. For example, religion forms the basis for group identity and induces solidarity among people through its norms, values and practices: these make them feel socially and ideologically different from non-members of the group (See Enchill, 2014). Fox and Sandler (2005) further argue that religious doctrines and belief systems have the potential to generate conflicts, because of certain interpretation and understanding of doctrines, which form the basis for religious beliefs. Another significant role of religion in the generation of security challenges is its incorporation of emotionally evocative and highly memorable symbols, myths and rituals that can motivate members individually and collectively and form the basis for violent actions and for justification of such actions (Enchill, 2014).

However, it is possible that religion may be used as camouflage for ethnic or political motives (Hexham, 2002). Hence, Møller (2006) does not see any significant connection between conflict 
and religion, even with the high probability of Islamic states being prone to conflict or terrorism. In other words, the predominance of one brand of religion over another does not predestine a state for conflict or determine the patterns of conflict (p.38).

Religious extremism in this chapter is defined in terms of the expression of extreme or violent actions or jihad on the basis of particular interpretations or understanding of religious teaching or scripture, especially the Koran. In particular, we examine the (online) communication behaviours of Islamic extremists/terrorist groups in West Africa and Somalia. And we focus on Boko Haram of Nigeria, Ansar dine, and The Movement for Unity and Jihad in West Africa (MUJAO) of Mali, and Al Shabaab of Somalia. An overview of these extremists under study is carried out below.

Fig. 1: Map of West Africa

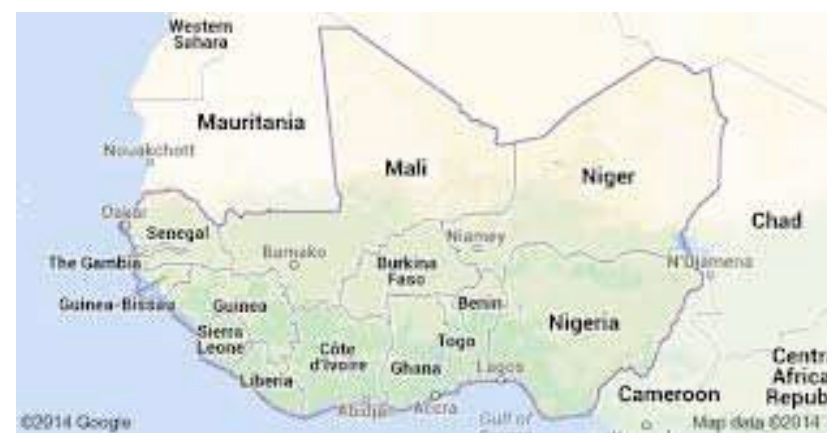

\section{Boko Haram}

Boko Haram was founded in 2002 by Mohammed Yusuf, a Muslim cleric, in Maiduguri, (Northeastern Nigeria). "Boko Haram" is a nickname for Jama'atu Ahlis Sunna Lidda'awati walJihad, meaning "people committed to the propagation of the Prophet's Teachings and Jihad." They began armed uprising in June 2009 when they claimed that they were fighting corruption, but their main aim was to Islamize the entire northern states of Nigeria. The uprising was confronted by the Nigerian military, resulting in the death of over 700 people mostly the sect members including their founder (see Chiluwa and Adetunji, 2013). The death of Mohammed Yusuf escalated the violence in the north perpetrated by Boko Haram now led by Abubakar Shekau who was deputy to Yusuf. Their targets have been churches, drinking pubs, army barracks, police stations and government facilities and agencies (Chiluwa, 2015).

According to the United States National Consortium for the Study of Terrorism and Responses to Terrorism (START), only Afghanistan's Taliban are ahead of Nigeria's Boko Haram on the list of global terror (Chiluwa, 2015). Hence, on the 13th of November, 2013, the United States Department of State announced the designation of Boko Haram and Ansaru as Foreign Terrorist Organisations (FTOs) (START November, 2013). Despite local and international efforts to arrest 
the activities of this group, they have continued their violent assaults in Nigeria and neighboring West African States. The group is said to have split into three factions operating in Cameroon, Chad and Niger some possible links to some terrorist groups in North Africa (Onuah and Eboh, 2011 cited in Chiluwa, 2015).

$\mathrm{BH}$ wants Northern Nigeria to return to the rule of a Caliphate, as it was prior to the Amalgamation of Nigeria in 1914. Northern Nigeria, southern Niger and Cameroon were then under the rule of the Sokoto Caliphate between 1850 and 1960 (Adesoji, 2010; Pérouse de Montclos, 2014). This is similar to the goal of ISIS - to establish a Caliphate of all Muslims under one supreme leader. A caliphate is a traditional Muslim form of government, in which the leader (or "caliph") is viewed as a political and religious successor to the Prophet Muhammad. Presently, the Islamic State's caliphate is thought to include several cities across northern Iraq and Syria.

In November, 2012, the BH leader, in a 39-minute video entitled: "glad tidings, o' soldiers of Allah," posted in a jihadist forum, praised jihadist movements across the world and in particular, labelled the United States, Britain, Israel and Nigeria as enemies of Islam. In a similar message, Shekau, on behalf of BH joined other terrorist groups in Egypt, Libya, Morocco and Tunisia to pledge their allegiance to ISIS on the $17^{\text {th }}$ of March, 2015. In the message, he told Abu Bakr alBaghdadi (known to his followers as "Ibrahim Caliph"): "we announce our allegiance to the Caliph... and will hear and obey in times of difficulty and prosperity..." According to Jim Muir, (a BBC news correspondent in Beirut), this alliance means that $\mathrm{BH}$ has become a global franchise (BBC, March 7, 2015). Incidentally, BH has carried out series of attacks, some of which have been their "deadliest" in northern Nigeria since the Nigerian new government was sworn-in in May, 2015. According to Amnesty International, about 1600 people have been killed since June, 2015 in Nigeria, Niger, Chad and Cameroon.

However, in the last few months, the Nigerian government has successfully pushed back BH, restricting them to mere "soft targets," and has rescued communities and thousands of people previously held hostage by the group (Vanguard, $27^{\text {th }}$ September, 2015). Although, the Nigerian government claims to have defeated Boko Haram, the group has remained active in the north and still carries out intermittent attacks on Mosques, villages and markets. Thus, BH remains a serious global threat.

Interestingly, on January $2^{\text {nd }}$ 2018, Abubakar Shekau, the Boko Haram's leader appeared in a video amidst renewed series of attacks claiming responsibility for the attacks in Maiduguri, Gamboru and Gamboa (northern Nigeria) during the festive season. BH had attacked a convoy of Nigerian soldiers, and sent suicide bombers into crowded markets in towns across northeast Nigeria in December 2017. In a 31-minute video, Shekau, speaking in Hausa announced that the group was in "good health" and that the Nigerian troops cannot do anything against them. The message came a few days after the Jihadists killed 25 people about $20 \mathrm{~km}$ from Maiduguri. Some gunmen riding a motorcycle had attacked a logging site where people were loading firewood into 
vehicles. (https://www.theguardian.com/world/2018/jan/01/nigeria-toll-in-boko-haram-attackon-loggers-rises). 50 people were killed, while many others were injured in November, 2017 when a suicide bomber attacked a mosque in Mubi (Adamawa state). https://www.vanguardngr.com/2017/11/suicide-bomber-killed-60-injured-scores-adamawa/). However, the Nigeria president in his New Year message still claimed that $\mathrm{BH}$ have been defeated.

\section{Ansar Dine}

Ansar Dine (i.e. defenders of the faith) is a paramilitary terrorist group based in Northern Mali. The group is led by Iyad Ag Ghaly - a former senior commander of a rebel military group in Mali in the 1990s; he had also served as a negotiator for the release of Westerners kidnapped by al Qaeda in the Islamic Maghreb (AQIM). Ansar Dine emerged after the military coup in Mali that ousted Amadou Toure in March, 2012. Alongside the Tuaregs' National Movement for the Liberation of Azawad (MNLA), they declared the independence of the "Islamic Republic of Azawad," after capturing the northern towns of Gao, Kidal and Timbuktu. The alliance with MNLA broke up when Ansar Dine and MUJAO, (another Islamic terrorist group with links AQIM), resorted to implement Sharia laws in the new state; MNLA had wanted only a secular independent state. This resulted in a conflict between the armed groups and by July 2012, Ansar Dine had gained full control of northern Mali (See $B B C$, May 27, 2012). By the invitation of the Malian government, the French military, with a UN mandate and some African Union members began a military operation against the Islamist militants and by February 2013, the Islamists had been driven out and the Islamist-held territory was recaptured. The main objective of Ansar Dine is to impose the Sharia throughout Mali.

Although based in Mali, Ansar Dine is said to be a transnational outfit; their leader Ag Ghaly was said to receive Salafist religious training from Pakistani missionaries in northern Mali in the 1990s and later rekindle his Islamist views during his diplomatic service in Saudi Arabia years later. Ansar Dine is believed to be funded by Qatar with its membership drawn from Nigeria, Pakistan, Somalia, Afghanistan and Algeria (Lambert and Warner, 2012). Global in its outreach, the group brought its efforts online by releasing a propaganda video and establishing a presence in jihadist chat rooms.

Ansar Dine has claimed responsibility for several attacks including suicide bombings in Mali and neighboring states. For instance, the group claimed responsibility for four different attacks in Mali in February, 2016. In Kidal, the suicide and rocket attack on a UN base left six people dead. The group claimed that the attack was carried out in retaliation to the German president's visit to Mali when he promised to contribute soldiers to the fight against Islamic terrorists in Mali (Weiss, 2015). They had also detonated improvised explosives on three UN vehicles and claimed to target a UN camp in Kidal with rockets (Weiss, 2016). In 2015 the Ansar Dine leader released 
an audio statement in which he threatened France and rejected any peace accord in Mali (Weiss, 2016). The United States Department of State designated Ansar Dine as a Foreign Terrorist Organization (FTO) in March, 2013.

\section{Movement for Unity and Jihad in West Africa (MUJAO)}

The Movement for Oneness and Jihad in West Africa (MOJWA, or MUJAO in French) is a Salafist terrorist group that broke off from A-Qaeda in the Islamic Maghreb (AQIM) in 2011. They formally announced their existence following the abduction of three humanitarian workers from a Saharan refugee camp in Tindouf on 23 October 2011. (http://www.start.umd.edu/baad/narratives/movement-oneness-and-jihad-west-africa-

mujao) Although the group became an independent terrorist group with the aim of spreading Jihad in West Africa, especially areas not within the scope of the operation of AQIM, it continued to be affiliated to AQIM. They operated in southern Algeria and Northern Mali and collaborated with Ansar Dine and the Movement for the Liberation of Azawad (MNLA) to fight for and declare the independence of the Islamic Republic of Azawad in 2013. (https://www.trackingterrorism.org/group/movement-unity-and-jihad-west-africa-mujao)

MUJAO's leaders were known to be drug traffickers in the Sahel and southern Algeria. One faction of the group merged with Mokhtar Belmokhtar's Al Mulathameen to form a new group called Al-Mourabitoun in 2013. The group claimed to espouse the ideologies of those of Osama bin Laden and Mullah Omar (the Taliban leader). However, they emphasize the ideologies of some West African Islamic historical leaders such as Cheikhou Amadou, Usman Dan Fodio and El Hadi Umar Tall. (See https://www.trackingterrorism.org/group/movement-unity-and-jihadwest-africa-mujao). According to Insidegov.com, MUJAO has been responsible for at least 33 attacks in three countries (Mali, Niger and Algeria) resulting in 71 deaths.

(http://terrorist-groups.insidegov.com/1/7448/Movement-For-Oneness-And-Jihad-In-West-

Africa). In the Battle of Konna in January, 2013, MUJAO temporarily gained control of Konna but was driven out by the Malian army and its allied French armed forces. MUJAO was sanctioned by the United Nations Security Council in 2012 as part of Al-Qaeda.

\section{Al Shabaab}

Al Shabaab (i.e. Mujahedeen Youth Movement) was founded in 2006 as a radical arm of the Union of Islamic Courts in Mogadishu and is estimated to control over 7000 fighters (Calamur 2013; Chiluwa, 2015). Their leader Aden Hashi Ayro was killed in a US air strike in May, 2008 and was replaced by Ahmed Abdi Godane (or Abu Zubayr) as their top commander (Ungerleider 2013). Al Shabaab, which is an affiliate of Al-Qaeda, operates from the Southern and Central Somalia with a mission to create a fundamentalist Islamic state in Somalia. Members of Al 
Shabaab are said to be drawn from different clans and regional sub-clans and their militant groups (Chiluwa, 2015). They also exert influences and recruit radicalized youths from elsewhere in the African sub-regions and had kidnapped and conscripted schoolchildren to fight in battles. According to Gentleman (2011), educated Westerners work for Al Shabaab and several SomaliAmericans have been suicide bombers.

Al Shabaab has resisted and fought against the Transitional Federal Government (TFG) of Somalia and its allies, including the African Union Mission in Somalia peacekeepers, and nongovernmental aid organizations. The group is said to be more interested in their nationalistic battle against the TFG and hopes to regain control of Southern and Central regions of Somalia, which it had attacked and taken over in 2006 but was overthrown by the Somali Government with the help of Ethiopian forces. The in-fighting and military pressure from the Somali Government and its allies has continued to liberate key towns from Al Shabaab. However, the group had continued to threaten neighboring African countries and Western interests in Africa (Chiluwa, 2015). Al Shabaab had claimed responsibility for several bombing attacks including suicide bombings in Mogadishu and in central and northern Somalia. The attacks had targeted Somali Government officials and their allies. Al Shabaab also claimed responsibility for the twin suicide bombings in Kampala (Uganda) on 11 July 2010 that killed over 70 people who gathered to watch the World Cup.

In August 2014, the Somali government led a military operation known as "Operation Indian Ocean" to recapture some insurgent-held territories in the countryside. And on September 1, 2014, a U.S. drone strike killed the Al-Shabaab leader (Ahmed Abdi Godane), and the Somali government offered a 45-day amnesty to all moderate members of the group (Associated Press, September 5, 2014). However, the militant group has remained very active and has been responsible for several deadly attacks. An example of their recent activity was the December 2017 Mogadishu Market bombing that killed 500 people and injured many more. This was viewed as one of the most deadliest single terrorist attacks since 9/11. Al Shabaab also claimed responsibility for the Mogadishu hotel attacked in which 23 people were killed. (https://www.theguardian.com/world/al-shabaab). On the 29th of September 2017, the group attacked an army base killing eight soldiers and looting the place (Aljazeera, September 29, 2017). These were among several other deadly attacks. The US Department of State designated this group as a foreign terrorist organization in 2008 (See http://www.cfr.org/somalia/alshabaab/p18650).

\section{Religious Extremism in West Africa}

Africa is known as a religious continent with peoples of extreme spirituality that cut across three predominant religious families - traditional religion, Islam and Christianity, each of which is present in large numbers. As highlighted above, religious extremism has been used to describe any faith-induced action that is a deliberate attempt to inflict harm on others. Liebman (1983) 
views religious extremism as the desire to expand the scope, details and strictness of religious law; social isolation; and the rejection of the surrounding culture. It includes the formation of violent religious movements, and the expression of extreme and unjust positions or actions in the name of a religious faith. Based on some controversial interpretations of religious doctrines, extremists are usually willing to murder anyone against their faith by embracing ideologies that consent to violence in the service of God. Non-members of their faith are generally viewed as infidels and as enemies of God. Significantly, extremists are also ready to sacrifice their own lives in the name of martyrdom.

As is common with all Islamic extremists, terrorist groups in Africa reject alternative views and seek to impose their beliefs, ideologies and values on non-adherents through force or indoctrination and are intolerant of beliefs and perspectives of other religions. Boko Haram for instance reject Western education and social lifestyle, and have carried out attacks on churches, schools, beer halls and pubs. They have also attacked Mosques and moderate Muslims accused of compromising Islamic teachings. They reject the Nigerian democratic government and insist on the creation of an independent Islamic State in Northern Nigeria strictly governed by Sharia laws. Members congregate in mosques, wear long gowns and grow longs beards (Chiluwa \& Adetunji, 2013).

Like Boko Haram, Al Shabaab of Somalia enforce a harsh interpretation of the Sharia and also prohibit Western lifestyle and entertainment. Hence, they condemn Western education, music, movies, haircuts, etc. They also attack non-Muslims, including Christians and are a major threat to humanitarian and other international workers (Chiluwa, 2015). For instance, the group was said to be responsible for the assassination of Somali peace activists, international aid workers, journalists and numerous civil society personnel, and was blamed for blocking the delivery of aid from some Western relief agencies during the 2011 famine that killed thousands of Somalis (Masters, 2013 cited in Chiluwa, 2015).

Extremists generally set up a binary "them and us" world view, with the intention of dividing communities along communal lines, and enforcing this through violence. They also inhibit the civil liberty and human rights of others on the basis of gender, sexuality and race. Very often however, some adherents of such religions consider violent positions as fanatical, unacceptable and unrepresentative of their faith, just as some moderate Muslims have often denounced and dissociated themselves from the extreme positions of Islamic militants and terrorists.

\section{Communication Techniques by Extremist and Terrorist Groups}

Terrorist groups across the world are constantly developing methods and techniques in their modes of operations, some which include sophisticated systems of technological communication. The continual success of several well-planned attacks around the world is a clear proof that terrorist organizations have perfected their communication methods. In recent times, the Internet has provided Islamic extremists with variety of resources targeted at young people, and 
connecting them with online Islamist recruiters. According to Awan (2017), ISIS for example, has developed an app to spread their propaganda through images and the streaming of violent online videos. Some of their websites and videos are specifically targeted at youth audiences, disseminating extremist doctrines and propaganda through colorful cartoons and games. In Africa, the Boko Haram of Nigeria and the Al-Shabaab of Somalia have consistently used the Internet to wage a cyber-war. Al Shabaab for instance, has been accused of "twitter terrorism", and hate-speech warranting the shutting down of their Twitter accounts at different times (Gentleman, 2011, p. 2; Chiluwa, 2013).

Before the prevalence of information technology and the adoption of the Internet for terrorist propaganda and operations, Al-Qaeda communicated with its member and allies (e.g. in Turkey) through face-to-face communication, courier services, telephone, the mass media and the Internet. They claimed responsibility for attacks and issue political statements in the mass media. Through personal contacts at members or supporters' homes or at a specified location, they were also able to transmit information faster and easier. Communication by courier was transmitted through persons who delivered packages and mail to their destinations. Courier people were usually members of the organization who delivered secret notes and instructions, as well as money, and other items, including weapons to designated places (Pekgozlu, Ozdemir and Ercikti, 2007). Up till the present times, terrorist groups and secessionist movements still communicate through the mass media. Boko Haram of Nigeria and the Ansar Dine of Mali still issue threats and make "statements" and "declarations" as well as publish "press releases" in the mass media and the Internet. The example below is an excerpt from one of Boko Haram's statements published in the Vanguard newspaper (August 9, 2009).

\begin{abstract}
"For the first time since the killing of Mallam Mohammed Yusuf, our leader, we hereby make the following statements: That we have started a Jihad in Nigeria which no force on earth can stop...That from the Month of August, we shall carry out series of bombing in Southern and Northern Nigerian cities, beginning with Lagos, Ibadan, Enugu and Port Harcourt..." That we shall make the country ungovernable, kill and eliminate irresponsible political leaders of all leanings, hunt and gun down those who oppose the rule of Sharia in Nigeria and ensure that the infidel does not go unpunished...That very soon, we shall stir Lagos, the evil city and Nigeria's South West and South East, in a way no one has ever done before. Al Hakubarah..." (Chiluwa, 2017, p.331).
\end{abstract}

According to Bogart (2013), Al-Qaeda like other terrorist groups, is known for using religious terms, along with code-words usually referred to as "veil speech" in their communication exchanges in order to dupe persons and authorities. This form of "language protection" is a commonly used tactic by extremist groups; for example, writing emails and website literature in Arabic, or other dialogues that may be harder to translate. Jihadist websites also disguise text in Arabic, along with using URLs that change constantly and are often password-protected, making it difficult for Westerners to track (p.1).

The prominence of Internet communications in contemporary social life and the application of the Internet and ICT to advance terrorist activities have given rise to the concept of "Terrorism 
2.0", where terrorist groups have extensively adopted web 2.0 applications and semantic technology tools to propagate their activities (Ishengoma, 2013). This is especially made possible by the existence of the Dark Web and the Deep Web; that is, a body of cryptic websites and online data that are not publicly available on popular search engines, yet allow for communication and dissemination of information without being detected or tracked by governments and intelligence agencies (Harsh, 2015). The Dark Web is encrypted with tools such as TOR (The Onion Router) and I2P. There is also the e-commerce site - "The Armory" in the Dark Web; where terrorist organizations easily transact in weaponry (arms and ammunition, explosive devices, etc.) through crypto-currencies such as the BitCoin (Harsh, 2015).

Terrorist groups also use other forms of encrypted communication, within the Deep Web in recruiting and radicalizing members, as well as planning attacks. This communication takes place via private messaging applications such as WhatsApp, Snapchat, and iMessage where messages are not only encrypted, but can also be easily deleted without leaving a trace. They also encrypt their messages in public online platforms such as eBay (an online market) and Reddit boards. When encryption is not entirely possible, the Chaffing and Winnowing technique is used, where secret messages are subliminally inserted in a mix of seemingly regular messages (Harsh, 2015). Social media pages and accounts run by the different terrorist organizations, further provide platforms to propagate their messages and ideologies, and attempt to indoctrinate or radicalize other Internet users. They also plan and carry out attacks, and raise funds through some complex digital platforms (Bott, Dickens, Moffitt, Rowley, Smith, \& Thompson, 2009; Ishengoma, 2013).

According to Conway (2017) "today's Internet does not simply allow for the dissemination and consumption of "extremist material" in a one-way broadcast from producer to consumer, but also high levels of online social interaction around this material" (p. 80). There are models developed to describe the recruitment process in radicalization, and evidently, this is largely done online. The Berger's model, for instance, notes that terrorist recruiters usually use Twitter and Facebook to identify target recruits, develop personal friendship/relationship with them and sustain communication while consciously radicalizing them (Operation250). In the process, these recruiters build micro-communities around the recruit, as the main recruiter engineers seemingly random connections between other terrorists and the recruit. In the process, isolation takes place, and the recruit gradually replaces his/her former real-life friends with the new ones made online. These are geared towards ensuring that the recruit learns the group's ideology, as well as test the recruit's tendency to take orders. Eventually, the recruiters interact with their recruits on private or encrypted messaging platforms such as WhatsApp and Telegram. The radicalization cycle is completed once it is ascertained that the recruit will either remain at his or her location to plan attacks or travel out of their country to join the terrorist group. This recruit then sets out to radicalize others.

Bertram and Ellison (2014) report that terrorist groups in Sub-Saharan Africa first gained online presence in 2008. At the time of their study, 112 websites were traceable to Sub-Saharan African terrorist groups, and a significant fraction of these groups have visible web presence. South 
Africa and Nigeria had the highest number of these websites. The Somalia-based Al-Shabaab for instance, disseminated information about the deadly Westgate terrorist attack, as well as claim responsibility for the attack on Twitter. Below are a few examples from their English language Twitter account:

MSMPress Office@HSM_PR

The Mujahideen entered \#Westgate Mall today at around noon and are still inside the mall, fighting the \#Kenyan Kuffar inside their own turf.

MSM Press Office@HSM_PR

The attack at Westgate Mall is just a very tiny fraction of what Muslims in Somalia experience at the hands of Kenyan invaders.

HSMPRESS@HSMPRESS1

The Mujahideen strive to liberate Muslim lands \& lift the oppression from Muslims who are forced to live under the heel of Kafir Invasion (Chiluwa, 2015, p9-10).

Boko Haram, also constantly makes attempts to define the tone of public rhetoric about them, and make it a duty to respond to public rumours, especially those propagated by their perceived enemies (Mahmood, 2017). As highlighted above, the group's public discourse in the past was initiated by press statements or interviews, granted by appointed spokespersons to local journalists; however, they have quickly moved from traditional means of public discourse to the more trendy, resourceful and spontaneous affordances of Internet technologies. In fact, the Internet has become almost the exclusive means of public communication used by the group (Mahmood, 2017).

The group had previously operated Twitter accounts, namely@BokoHaram (Chadian Border) and@BokoHaram (Republic of Arewa), for the propagation of their ideologies, and advancement of their objectives (Chiluwa \& Adetunji, 2013; Chiluwa \& Ajiboye, 2014). Below are examples from their English language Twitter account:

(a)Boko_Haram. We love Nigerians; it's only the Nigerian polis, Nigerian army, drunkards, prostitutes, politicians, usurers, teachers, touts we can't stand. @Boko_Haram. Armypeople you are hungry, polis you are tired. Go home. We are your friends. Our enemies are the infidels at Aso Rock \#gaskiya.

@Boko_Haram. Jonathan, abati, omokri are a threat to Nigeria not Boko Haram. We fight for your liberation even though you are not grateful \#longterm.

@Boko_Haram. MEND is after money, we are after ideals. Ideas that come at the right time flourishes. \#deadideals (Chiluwa \& Ajiboye 2014, p. 334335) 
In recent times, Boko employ high resolution YouTube videos as one of their main outlets for information dissemination to address government at various levels, the media, and the Nigerian people, among others. Through their YouTube channel, they offer coverage of attacks, make verbal threats of potential attacks, and make bold statements on the success of planned attacks, as well as take responsibility for attacks. Since 2015, the group has embraced a more global outreach by broadcasting mostly in Arabic (almost 90\% of messages), rather than Fulfude and Kanuri, which have more localized audiences (Mahmood, 2017). These videos are distributed across various social networking sites, earning the group its desired publicity.

There are also reports that many of the attacks carried out by Boko Haram are co-ordinated by mobile telephony (Jacob \& Akpan, 2015). This, had in 2013, necessitated the shutdown of mobile telephony services in some states in the Northeastern region of Nigeria where insurgency was prevalent.

\section{Conclusion}

This chapter has examined religious extremism and its relation to violent conflict. It has specifically described the extremist violent activities of some identified African terrorist groups, and how contemporary media and the Internet have provided dynamic platforms for disseminating their message and ideology. Unfortunately, despite government and allied confrontations of these terrorist groups, and the claims that they have been defeated, the Islamist militants are rather expanding and are still carrying out deadly attacks. And interestingly, the media and Information technology, including the Internet support the communication options that promote disseminating of extremist ideas, as well as propaganda, recruitment and mobilizing, incitement, radicalization and fund-raising (see Chiluwa, 2017). The question here is: how can religious extremists or terrorist groups be restricted from using the Internet, for example? Conway (2005) has suggested that just as there is information available for terrorist groups on how to disseminate their doctrines and move money, and recruits around the world, there are also data that can trail them and check their activities. She notes that law enforcement agencies have been the main instigators of these initiatives and have been joined by other government agencies and concerned individuals and hacktivists. She suggests intelligence gathering, especially from open sources and innovative ideas on intelligence sourcing; new technologies to be developed and deployed in the fight against terrorism, and sanitizing government sites. The latter means, avoiding providing information that might be useful to terrorists in planning further attacks. For instance, after 9/11 some state and private web page operators took large amounts of material off the Internet (Conway, 2005).

Some have suggested that government should simply block terrorist websites, which some governments have already done. But others feel this measure may be complicated and have their 
legal implications. Rather, they suggest "filtering" of such websites like the German government has done in passing a law to protect children from pornography and could be extended to block sites that promote terrorist acts. Australia was said to be testing a filtering system for both child pornography and materials that advocate terrorism (Mantel, 2009).

In West Africa unfortunately, there appears to be no form of legislation or initiative that aims at studying the activities of extremist and terrorist in the media and the Internet. We suggest that African nations, especially countries that are prone to or host terrorist activities like Nigeria, Mali and Somalia should threaten their counter-intelligence and terrorist intelligence services. We advocate strong initiatives and legislation that aim at censoring or prohibiting terrorist behaviours on the Internet.

\section{References}

Adesoji, A. (2010) “The Boko Haram uprising and Islamic revivalism in Nigeria." Africa Spectrum 45(2), 95-108.

Awan, I. (2017). Cyber-extremism: Isis and the power of social media. Society, 54(2), 138-149.

BBC (2015, March 7). Nigeria's Boko Haram pledges allegiance to Islamic State. http://www.bbc.com/news/world-africa-31784538

Bertram, S., \& Ellison, K. (2014) "Sub Saharan African terrorist groups' use of the Internet. Journal of Terrorism Research, 5(1). https://jtr.s andrews.ac.uk/articles/10.15664/jtr.825/

Bogart, N. (2013) "Terrorist organizations use variety of techniques to communicate with overseas cohorts." https://globalnews.ca/news/504972/terrorist-organizations-usevariety-of-techniques-to-communicate-with-overseas-cohorts/

Calamur, K. (2013). "Somalia's Al-Shabaab: 4 things to know." http://www.npr.org.

Chiluwa, I. (2017) "The discourse of terror threats: assessing online written threats by Nigerian terrorist groups." Studies in Conflict \& Terrorism, 40(4), 318-338, (Taylor \& Francis)

Chiluwa, I. (2015) "Radicalist discourse: a study of the stances of Nigeria's Boko Haram and Somalia's Al Shabaab on Twitter." Journal of Multicultural Discourses $10(2), 214-235$

Chiluwa, I. \& Ajiboye, E. (2014) "We are after ideals": a critical analysis of ideology in the tweets by Boko Haram.' Global Media Journal, African Edition. 8(2), 318-346

Chiluwa, I. \& Adetunji, A. (2013) "Twittering the Boko Haram Uprising in Nigeria: Investigating Pragmatic Acts in the Social Media. Africa Today, Vol. 59 (3), 82-102

Conway, M. (2017) "Determining the role of the internet in violent extremism and terrorism: Six suggestions for progressing research." Studies in Conflict \& Terrorism, 40(1), 77-98.

Conway, M. (2005) "Terrorist use of the Internet and fighting back." Paper presented at the Conference: Cybersafety: Safety and Security in a Networked World: Balancing Cyber-Rights and Responsibilities, Oxford Internet Institute (OII), Oxford University, UK, 8-10 September, 2005

Cornish, P. (2008). 'Terrorism, radicalism and the internet.' Report of a Private 
Roundtable Discussion, July 22. Chatham House. www.detica.com.

Enchill, C. (2014) "Religious militancy in West Africa: A comparative study of Ghana and Nigeria." Dissertation submitted to the University of Ghana, Lego. http://ugspace.ug.edu.gh

Fox, J. \& Sandler, S. (2005) "The Question of Religion and World Politics." Terrorism and Political Violence, 17: 293-303

Gentleman, J. (2011) "Somalia's Insurgents Embrace Twitter as a Weapon." The New York Times (December 14). http://www.nytimes.com/2011/12/15/world/africa/som

Harsh, A. (2015, November 15) "How terrorists communicate - Tech secrets of the Dark Web." Retrieved December 12, 2017 from https://www.linkedin.com/pulse/how-terroristscommunicate-dark-web-anurag-harsh/

Hexham, I. (2005) "Religious Extremism in Sub-Sahara Africa." WriteNet Paper No.19/2001 UNHCR Emergency and Security Service.

Ishengoma, F. R. (2013) "Online social networks and terrorism 2.0 in developing countries." International Journal of Computer Science and Network Solutions, 1(4). Retrieved December 12, 2017 from https://arxiv.org/abs/1410.0531

Jacob, J., \& Akpan, I. (2015) "Silencing Boko Haram: Mobile phone blackout and counterinsurgency in Nigeria's Northeast region. Stability: International Journal of Security and Development, 4(1). https://www.stabilityjournal.org/articles/10.5334/sta.ey/

Lambert, M. \& Warner, J. (2012) "Who is Ansar Dine?" Special Report to CNN. http://globalpublicsquare.blogs.cnn.com/2012/08/14/who-are-ansar-dine/

Liebman, C. (1983) "Extremism as a religious norm." Journal for the Scientific Study of Religion. 22(1), $75-86$.

Mahmood, O. (2017) "Boko Haram: what's in a message?" Institute for Security Studies. Retrieved December 12, 2017 from https://issafrica.org/iss-today/boko-haram-whats-in-amessage.

Mantel, B. (2009) "Terrorism and the Internet: Should websites that promote terrorism be shut down?” In: Understanding Terrorism, pp. 129-153 (CQ Researcher). https://www.sagepub.com/sites/default/files/upm-binaries/36306 6.pdf

Masters, J. (2013) “Al Shabaab.” Council on Foreign Relations, September, 23. http://www.cfr.org/somalia/al-shabaab/p18650, accessed on 23 October 2013.

Møller, B. (2006) "Religion and conflict in Africa with a special focus on East Africa." Danish Institute of International Studies. A DIIS's Defence and Security Studies Project https://www.files.ethz.ch/isn/20975/RP 06 6.pdf

Operation 250. "How do terrorists talk to you." Retrieved December 12, 2017 from https://www.operation250.org/how-to-tell-if-you-are-talking-to-a-terorrist/

Pekgozlu, I., Ozdemir, H. \& Ercikti, E. (2007) "Communication methods in terrorist Organizations: A case study of Al-Qaeda connected terrorism in Turkey.” In: Suleyman Ozeren \& Ismail Dincer Gunes (eds.) From Understanding Terrorism: Analysis of Sociological and Psychological Aspects, p. 281-293, (NCJ-225410)

Perouse de Montclos, M. (2014) "Boko Haram and politics: from insurgency to terrorism.” In: Marc-Antione de Montclos (ed.) Boko Haram: Islamism, politics, security and the state in Nigeria. Leiden: African Studies Centre, pp. 136-156 
Ungerleider, N. (2013). "How Al-Shabaab uses the Internet to recruit Americans." http://www.fastcompany.com/3018339/how-al-shabaab-uses-the-internet-to-recruitamericans.

Weiss, C. (2015, 8 March) "Rocket attack on UN base in Kidal kills 3, injures 12." https://www.longwarjournal.org/archives/2015/03/rocket-attack-on-un-base-in-kidal-kills3-injures-12.php.

Weiss, C. (2016, 30 November). "AQIM claims two attacks in northern Mali." https://www.longwarjournal.org/archives/2016/11/aqim-claims-two-attacks-in-northernmali.php 